\title{
Kommentar
}

\section{Vage symptomer - fatal utgang}

남

Engelsk oversettelse på www.tidsskriftet.no

Urosepsis i løpet av de første levemånedene er ikke helt uvanlig og forekommer hyppigst hos gutter, først og fremst pga. urogenitale misdannelser (1). Urethraklaffer, som kun forekommer hos gutter, manifesterer seg på ulike måter, og ved påvisning i fosterlivet kan uttalt hydronefrose gi grunnlag for avlasting prenatalt (2). Postnatalt vil en urosepsis kunne være det første symptomet om da ikke noen allerede har reagert på at gutten har en svak urinstråle. Obstruksjonen kan i enkelte tilfeller være såpass beskjeden at tilstanden først avklares etter flere år når barnet henvises pga. urininkontinens, ev. i voksen alder (3).

Den aktuelle sykehistorien er et godt eksempel på hvor utfordrende det kritisk syke spedbarnet kan fremstå. Opplysning om svak urinstråle må føre til videre bildediagnostikk. Ved ultralydundersøkelse av urinveiene vil man kunne påvise hydronefrose og fortykket blærevegg, når det foreligger urethraklaffer. Ultralyd er imidlertid en metode som er avhengig av undersøkerens erfaring og kompetanse, og påvisning av en eventuell hydronefrose forutsetter at pasienten er adekvat hydrert. Selve diagno- sen må verifiseres ved miksjonsuretrocystografi (MUCG), fordi bl.a. både en nevrogen og en ikke-nevrogen urinblære vil kunne gi det samme ultralydfunnet (4).

Barnets dårlige vektoppgang og generelt dårlige trivsel (failure to thrive) tilsier i seg selv en grundig utredning. En av årsakene til dette symptomkomplekset kan være en øvre urinveisinfeksjon, selv om barnet ikke har feber. Betydningen av å undersøke urinen hos alle spedbarn med uklare symptomer eller funn kan ikke understrekes ofte nok. Dette gjelder ikke bare ved mistanke om en bakteriell urinveisinfeksjon, men også ved tilstander som direkte eller indirekte rammer nyretubuli og/eller -interstitiet. Ikke bare kunnskap om elektrolytter, men også om $\mathrm{pH}$, aminosyrer (metabolsk screening) og glukose kan være avgjørende for videre diagnostikk.

Kort summert understreker kasuistikken at opplysning om svak urinstråle må forfølges bildemessig, at generelt dårlig trivsel alltid må utredes og at undersøkelse av urinen er svært viktig ved uklare tilstander hos spedbarn.
Hans-Jacob Bangstad

h.j.bang@online.no

Barnemedisinsk avdeling

Oslo universitetssykehus, Ullevål

Hans-Jacob Bangstad (f. 1949) er spesialist i pediatriog seksjonsoverlege.

Forfatter har fylt ut ICMJE-skjemaet og oppgir følgende interessekonflikter: Han har mottatt reisestøtte fra Ferring.

\section{Litteratur}

1. Mesrobian HG. Urologic problems of the neonate: an update. Clin Perinatol 2007; 34: 667-79, viii. viii.

2. Carr MC, Kim SS. Prenatal management of urogenital disorders. Urol Clin North Am 2010; 37: $149-58$

3. Khursigara N, McGuire BB, Flood H. Late presentation of posterior urethral valves. Can J Urol 2011: 18: 5739-41.

4. Jayanthi VR, Khoury AE, McLorie GA et al. The nonneurogenic neurogenic bladder of early infancy. J Urol 1997; 158: 1281-5.

Mottatt 18.6. 2012 og godkjent 22.6. 2012. Medisinsk redaktør Siri Lunde. 